2004-1006

\title{
INDUSTRIAL PROJECTS IN MANUFACTURING ENGINEERING EDUCATION
}

\author{
Richard Rothaupt \\ Technology Department \\ University of Wisconsin-Stout \\ Menomonie, WI 54751
}

\begin{abstract}
Presentation will describe the requirements of an industrial project for $U W$-Stout manufacturing engineering students and illustrate the process used to screen and select industrial projects for the senior design course. An industrial project recently completed by students will be described.

\section{Introduction}

Since 2001 the capstone courses in the Manufacturing Engineering (MfE) program at University of Wisconsin-Stout has focused almost exclusively upon industrial sponsored projects. The capstone course is a two semester sequence where the first semester course focuses upon research and design of a product and the building of a mock-up. The second semester is to design and build a functional automated machine to produce a product. Projects are managed by teams of students, industry contacts and faculty advisors. Projects completed in the past have varied from food production to robotic welding cells. In order for the students to complete these extensive projects the curriculum at UW-Stout has been designed to provide the students with a 'technical toolbox' which emphasizes practical engineering experiences in industrial applications.
\end{abstract}

In teaching manufacturing engineering principles, the Stout MfE faculty believes that it is important students learn the techniques of manufacturing processes so they may more fully appreciate the complexities of production methods. It is not sufficient to only expose the student to theory and textbook learning they must also have practical experience in setting up and operating production machines. These basic experiences allow the students to derive a deeper understanding of manufacturing and also a greater appreciation of the work done by a typical industrial worker whom they most likely will be supervising once they are on the job. This curriculum was designed in response to criticisms leveled at engineering schools by the Society of Manufacturing Engineers in their Curricula 2000 Report $^{1}$ and the Manufacturing Education Plan: 1999 Critical Competency Gaps ${ }^{2}$ document and in other papers which alleged that schools offer too few "practical" and "hands-on" courses. Stout has a rich tradition of teaching students technical skills that can only be taught in laboratory experience. By integrating theory and 
experimentation with practice not only are the students better educated but the business community benefits with the solution of real industrial problems. There are several courses in the UW-Stout Manufacturing Engineering program which may involve industrial based projects: Controls \& Instrumentation, Design \& Simulation of Manufacturing Systems, Facilities \& Manufacturing Systems Design, Capstone I: Product Design by Concurrent Engineering, and Capstone II: Manufacturing Systems Design.

This paper describes how the Manufacturing Engineering program at University of WisconsinStout has incorporated industrial sponsored projects into the senior level capstone course sequence. An example of an industrial project will be presented.

\section{Capstone at UW-Stout}

The manufacturing engineering program at Stout is focused upon the design and control of manufacturing processes/systems used in the production of products rather than the design of the product itself. This focus on the manufacture of the product implies that the capstone courses must have a strong emphasis on manufacturing process/system design. We have decided that for the students to demonstrate their understanding of manufacturing engineering principles they would be required to design and build a flexible automated manufacturing cell or special machine for the production of a product. These open ended problems require students to use their "toolbox" of skills and knowledge gathered from previous coursework. Examples of automated systems from previous semesters have produced items as varied as dominoes, pancakes, steel saw horses, and dental floss. The best projects incorporate knowledge from multiple courses in the curriculum including the courses: Computer Aided Manufacturing, Controls \& Instrumentation, Fluid Mechanics, Design \& Simulation of Manufacturing Systems, Flexible Manufacturing Systems, Design of Fixtures \& Tooling, Production \& Operations Management, Engineering Economy, Quality Engineering, Facilities \& Material Handling Systems Design, Material Removal Processes, Polymer Processes, Casting/Ceramics \& Powder Metal Processes, Bulk/Sheet Forming Processes, Joining and Fastening, Coating/Finishing and Packaging, and Statistics.

Since every project is different, they will all require a different skill set. But, all projects must address common areas as defined in the curriculum and must provide opportunities for students to demonstrate that they can properly analyze problems, gather information and make appropriate engineering decisions.

\section{Scope of Course}

The capstone experience in the Manufacturing Engineering program at UW-Stout is a twosemester course sequence. The projects are managed by teams of students with input from industry contacts and faculty advisors. In the first course, Capstone I, students experience the engineering design process by designing products or machines. The final detailed design is used in Capstone II, where students design and build an automated manufacturing system to produce the product. 


\section{Course Objectives and Limitations}

The overall learning objective for the capstone sequence is to immerse the student in a real life, professional problem solving experience. The capstone experience is team based but is expected to foster individual achievement through the success of the team. Capstone teams utilize independent thought and research while applying previously acquired skills, knowledge, and experience to the practical solution of an industrial problem. Team members learn to appreciate the structure, format, and procedure necessary in carrying a project through to completion.

Since it is an educational experience there are limitations to which projects we accept into the course. We generally specify that the product; should be no larger than a bread box, consist of multiple parts, must be capable of being produced in our facilities, must stay within certain cost limitations, and must be able to be completed within the time frame of the course. Although the classroom setting does impose limitations, these are very similar to constraints in actual practice in any industry.

\section{Lab Facilities}

UW-Stout is fortunate to have many fully equipped, up-to-date, undergraduate teaching laboratories specifically designed to promote understanding of the technologies involved in manufacturing. The department which houses the Manufacturing Engineering program has a total of 29 different labs which include a large machine shop, a sheet metal forming lab, a green sand foundry, a materials testing lab, a ceramics and powder metallurgy lab, a plastics forming lab, a packaging lab, a welding lab, a hydraulics/pneumatics lab, electrical/electronics labs and dedicated computer labs. The capstone students can also contract with students in a different class or a student professional society to out-source portions of a project. An example would be when capstone groups have contracted with students in the graphic printing lab to print boxes to be made by students in the packaging lab.

It is important to have a great deal of flexibility and cooperation between other faculty when doing open-ended industrial projects. One of the problems we have encountered is the fact that we do not have a specific laboratory for the building of capstone projects. Capstone projects can require large amounts of floor space and storage areas for equipment, tooling and supplies. Currently, the location of each project is dependent upon the equipment and floor space required by the project and which lab has the available space. This lab sharing method saves the extra cost of maintaining a special, fully equipped capstone laboratory, but it does present organizational problems for the professor when three different projects are in different locations. It has an aspiration of the UW-Stout engineering program to have a reserved laboratory for industrial projects.

\section{Project Selection}

Projects can be proposed by constituents from industry, entrepreneurs or students. Initial contacts are usually made through a faculty member or referred by the staff in the various centers on campus such as the Northwest Manufacturing Outreach Center, the Center for Innovation and Development or the Stout Technology Transfer Center. An initial meeting is scheduled with appropriate faculty and client. Location of the initial meeting depends upon the project. Many 
times a meeting at the industrial client's plant can be very helpful in clarifying the project and defining its scope. Students are never involved at this point in the process.

Projects must address a significant area of concern for the client but should not be on a hard timeline. What is preferred is a project that the client knows they would like to have completed but as yet, has not bubbled to the top of their to-do list. We are very leery of accepting projects which will cause problems for the company if it is not completed on time or if the student solution does not perform satisfactorily. It must be understood by the client that these are openended design problems that are being completed by those with an "engineering learners permit" and the projects are considered to be prototypes. If the project is applicable to program goals and within our guidelines, the client is invited to present the problem during a class meeting approximately three weeks into the semester. If the client cannot meet with the class the instructor can make the presentation. Normally, we have more project presentations than we have student groups. We will sometimes take on projects that have a completion timeline of one semester but primarily we desire projects that will run for two consecutive semesters.

Another important aspect of student/industrial projects is that the client company must be willing to designate a contact person at their facility who will act as a mentor for the student group. This has been extremely important in past projects. Company commitment has essentially vaporized when there has been a change in plant personnel or if the contact person is simply unwilling to provide the necessary support. The students must be able to get questions answered or items purchased and those activities are coordinated through the client contact person. Additionally, the contact person should be excited to work with the students and not view the situation as just another responsibility assigned to him/her. Student/client contacts are not daily or even weekly in nature, but as with the rest of the world, when you need information you wanted it yesterday and students are no different.

\section{Ownership of Project and Confidentiality Issues}

There are two basic formats under which we accept projects. The most common format is that the machine and all data generated by the project are owned by the client. Under this method the client pays for or supplies all items used in the project. If the project is to leave university property we will only accept the project if it is 100 percent client funded. Any project that is client funded will respect the client's confidentiality policies. There is no such thing as a typical cost for projects because the projects can vary dramatically each semester. Project costs have varied from a few hundred dollars to over $\$ 8,000$.

The second format is for those clients who do not want to receive a prototype at the completion of the project. Under this format the project is owned by the university and built using items from our storage area. Students have sometimes referred to these projects with the television show "Junkyard Wars". The MfE program has several large store rooms with an assortment of sensors, actuators, controllers, power supplies, motors, conveyors and many other items of automation. The students can use any of these items while building their projects. These projects are always considered to be concept prototypes with the university owning the project. A copy of the final report is supplied to the client if requested. Confidentiality is usually not considered to be an issue with unfunded projects.

Proceedings of the 2004 American Society for Engineering Education Annual Conference \& Exposition Copyright (C)2004, American Society for Engineering Education 
Students working on concept prototypes have access to a special MfE program account for student design projects. Money from this endowed account can be used to purchase items and supplies for use on student projects if those items are not available in our storeroom. All purchases must be approved by the faculty advisor. Students are required to demonstrate how the item will function in the project and show appropriate analysis for determination of correct size, fit, power, etc., plus supply all information necessary for purchase. A capstone purchase order form is completed by the student and signed by the advisor before a purchase order is made.

\section{Roll of Faculty}

The faculty members involved with the capstone course sequence can play the roll of a teacher, facilitator, mediator, or an upper level supervisor for a company. The faculty member directs the students without dictating the project. The faculty member must avoid providing too much input and thereby be the project leader with the students only providing the grunt work. There must be some willingness of the instructor to allow the students to be unsuccessful in certain design iterations. It would be wrong to shelter the students from every failure foreseen by the instructor and essentially quash creativity. The faculty advisor strives to keep the project moving forward, on time, with a solution that will satisfy the client's needs. Sometimes the faculty advisor is pushing students to complete a project and at other times they are doing their best to hold the students in check. It is not unusual for students to want to immediately start building the project and it is the faculty advisors job to force the students to design and plan the project and then build according to their plan.

\section{Capstone I}

Capstone I course requirements are based on the expectations for industrial projects. Students are required to prepare a formal written report about their semester's project work. They, in addition, must maintain a project journal used to record the team's work, calculations, product investigations, research data, and the minutes of team meetings. Students develop all necessary project layout drawings, including any assembly drawings deemed appropriate. Detailed drawings of all fabricated parts are made and a complete product bill of materials (BOM) is developed.

During Capstone I, a product manufacturing plan and cell layout must also be proposed. Dependent on the project, students are expected to identify and apply appropriate analytical tools when performing design analysis. Finally, all projects include a cost analysis.

The instructor assigns students to a particular team of three to five members to ensure that individual skills are evenly distributed between the groups. The students thereafter determine project responsibilities with their own groups.

\section{Capstone II}

Students in the second semester capstone course, design, build and demonstrate a flexible manufacturing cell that will produce a product. Depending upon the project, groups of six to eight students will comprise a team which the students self-select. It is the opinion of the faculty that students must have a strong commitment to the project and that is more likely to be attained if the student chooses their team and project. 
Each team in Capstone II will design and fabricate the part handling, tooling and the control system for their project. They are also required to produce documentation of the design process, and maintain a project journal. The documentation consists of: electrical, pneumatic and hydraulic schematics; any analysis or simulations used to prove the machine design; all part drawings necessary for fabrication of the machine; documentation necessary for machine control and write a machine operation manual. Students must also design a web page of their project that is loaded onto the Manufacturing Engineering program web site.

In addition to the two design reviews held during the semester, students are required to make a final formal presentation attended by the campus community, industrial sponsors, advisory committee members, students and parents, where they defend the design of the manufacturing cell and demonstrate its operation.

\section{Evaluation}

Course grades for both courses are assigned based on several criteria. Team oral presentations are assessed on the quality, quantity, organization, and completeness of the presentation. Project documentation is assessed on the professional quality of the report. Project designs are assessed on functionality, creativeness and simplicity of design, safety, reliability, manufacturability, and cost. All students perform peer evaluations on their teammates and the individual final grades are based upon a team project grade which is weighted by the peer evaluation scores. The industrial client is asked to evaluate their experience with a follow-up survey. This allows the client to express their satisfaction with their experience. Another method used for project evaluation is a discussion with the Manufacturing Engineering Industrial Advisory Board members who have attended the student's presentation. An informal discussion with board members and faculty occurs usually that same afternoon. Additionally, a student exit interview is conducted to evaluate the capstone course with the intent of improvement of future classes.

\section{Example of an Industrial Project}

Semi-Automated Castor Fork Assembly Cell - The Toro Company, Tomah, WI plant.

The client presented a problem involving the assembly process for their castor forks. The problem being that there are many variations in shaft and the fork size, requiring numerous changeovers to be performed with the weld fixtures. The current process creates large amounts of downtime during fixture change-over and was currently being run with a batch size of 150 parts. The goal of the project was to design a flexible welding cell that would handle any variation in castor fork models and reduce robot downtime plus bring the system closer to one piece flow.

Students visited the plant and video taped the current process of fixture change over and interviewed workers and supervisors. They also acquired sample parts and drawings of all castor forks. The parts were analyzed to discover whether there were common fixture reference points that would accommodate all parts. Over the following weeks students brainstormed several possible solutions which were discussed with the faculty advisors. 
The final design (fig. 1) allowed adjustments to be made quickly to accommodate any fork or shaft model and nearly eliminated robot down time caused from fixture change-over. The system consisted of two pallets with two fixtures each. Each fixture held one part to be welded and was attached to the pallet which would independently shuttle into the robot welding area. The system allowed the operator to safely work outside the robot envelope while loading/unloading parts at the same time the welding operation was taking place on the second pallet. With the loading and unloading process happening simultaneously with the welding process, the robot no longer needed to be inactive. The designed allowed four different castor fork models to be loaded into the fixtures per welding cycle. This eliminated the need to produce large batches of parts and would allow for a reduced caster fork inventory.

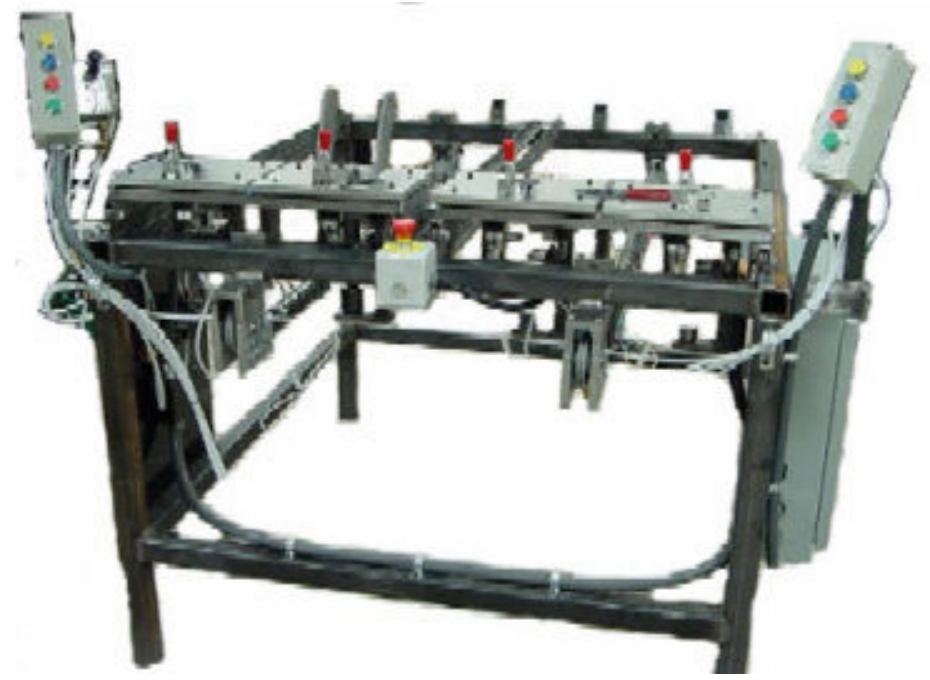

Figure 1. Castor Fork Assembly System

\section{Problems Incurred Conducting Industrial Projects}

Success of the projects cannot simply be a measure of successful completion of a machine. Student evaluation must take into account unforeseen project variables such as: parts ordered did not arrive when promised, thereby delaying the projects completion; or company contact/mentor goes on vacation or changes jobs; or the company goes through major internal changes and looses interest in project; or what seemed like an innovative design, simply does not work satisfactorily even though everyone thought it would; or a group member does a poor job with their portion of the work or drops out of school. Every one of these problems has occurred in various industrial projects at UW-Stout. Sometimes it means students must jump to a new project or they simply finish their original design as an in-house concept prototype.

Confidentiality or non-disclosure agreements can be a protracted process to complete which usually involve university legal advisors. While this is an important consideration for some companies, we have sometimes finished projects before the lawyers have completed discussions. It is best to start as early as possible if a non-disclosure agreement is required. 
A supposed limitation of industrial projects in the capstone experience is attributed to the variability between projects. Some faculty members like to be able to certify that every student who graduates from a program has a certain skill set or a "stamp of approval". With the variability of projects it is sometimes impractical that all students receive the same experiences. To help counteract this it is important that the faculty advisors choose projects carefully keeping the goals of the program firmly in their thoughts to help insure the soundness of the student's experience.

There is also no doubt that industrial projects require more work by the faculty than an in-house project. But the advantages of industrial projects such as the excitement student's feel when working on a "real" project, or the good will that is generated with client companies, and the positive publicity, these always seem to outweigh the extra work.

\section{Concluding Remarks}

Extensive industrial based capstone projects can be extremely rewarding to the students, faculty and program if projects are chosen carefully. Choose projects that meet the goals of the program and are within the capacity of the faculty, laboratory facilities and budget. It is absolutely necessary to have a willing contact person/mentor assigned to the project at the client company. Be sure to establish a system that clients and students understand for the ordering of parts for projects, a payment process, shipping procedures, and the approval and documentation of purchases.

All industrial projects require an extensive amount of time outside of class for group meetings, trips to industrial sites, contacting suppliers, fabricating the machine or cell, and troubleshooting. But, it truly becomes a passion for the students to complete these projects. Many graduates have said that it was the most rewarding experience of their school career because it allowed them to "put it all together" into one comprehensive project.

\section{References}

1. "Manufacturing Education Plan: 1999 Critical Competency Gaps", SME Report, 1999

2. Wells, D., Editor, Manufacturing Education for the $21^{\text {st }}$ Century, Volume 1: Curricula 2000 Report. Dearborn, MI: Society of Manufacturing Engineers, 1995.

3. Rothaupt, R., Stradins, L., (2003). A complete approach to the capstone experience. Proceedings of the 2004 American Society for Engineering Education Annual Conference \& Exposition.

\footnotetext{
Biography

RICHARD ROTHAUPT is an Associate Professor of Manufacturing Engineering since 1995 and is currently Program Director for Manufacturing Engineering at the University of Wisconsin-Stout. He holds a Ph.D. from Colorado State University and M.S. and B.S. from University of Wisconsin-Stout.
} 